\title{
Montbrison-Moingt
}

Impasse du 8-Mai

\section{Alegria Bouvier}

\section{(2) OpenEdition}

12 Journals

Édition électronique

URL : http://journals.openedition.org/adlfi/1488

ISSN : 2114-0502

Éditeur

Ministère de la culture

Référence électronique

Alegria Bouvier, « Montbrison-Moingt », ADLFI. Archéologie de la France - Informations [En ligne], RhôneAlpes, mis en ligne le 01 mars 2008, consulté le 02 mai 2019. URL : http://journals.openedition.org/ adlfi/1488

Ce document a été généré automatiquement le 2 mai 2019.

(c) Ministère de la Culture et de la Communication, CNRS 


\title{
Montbrison-Moingt
}

Impasse du 8-Mai

\author{
Alegria Bouvier
}

Identifiant de l'opération archéologique : 9727

Date de l'opération : 2008 (EV)

1 Un projet d'aménagement immobilier, dans un secteur de la plaine du Forez situé entre Montbrison, ville médiévale et Moingt, siège d'une occupation antique puis médiévale très importante, a suscité la mise en oeuvre d'un diagnostic archéologique. En particulier se posait la question de la localisation d'une maladrerie et d'une église Saint-Lazare, mentionnées dans les textes.

2 Mais l'opération de fouille d'évaluation dans une emprise de $2040 \mathrm{~m}^{2}$ n'a mis en évidence aucun indice d'une occupation ancienne. Les seules structures reconnues, quelques drains et le mur de clôture d'une parcelle, sont attribuables aux périodes moderne et/ou contemporaine. Le secteur sondé semble donc être uniquement voué à une activité agricole, comme l'atteste le cadastre napoléonien, au moins depuis la fin du XVIII ${ }^{\mathrm{e}} \mathrm{s}$. 
INDEX

Thèmes : mur

Index chronologique : ép. contemporaine

Index géographique : Rhône-Alpes, Loire (42), Montbrison

operation Fouille d'évaluation (EV)

\section{AUTEUR}

\section{ALEGRIA BOUVIER}

INRAP 